\title{
Pemanfaatan Lingkungan Sekolah sebagai Sumber Belajar dalam Lesson Study untuk Meningkatkan Metakognitif
}

\author{
Yuni Pantiwati \\ Universitas Muhammadiyah Malang \\ J1. Raya Tlogo Mas No.246, Malang, Jawa Timur 65I44 \\ surat elektronik: yuni_pantiwati@yahoo.co.id
}

\begin{abstract}
ABSTRAK
Pemanfaatan lingkungan sekolah dengan dua pola yaitu di dalam kelas dan di luar kelas. Kegiatan di dalam kelas memperhaatikan tujuan, materi, trategi, karakter siswa, dan alokasi waktu, sedang di luar kelas dengan cara bebas, terkontrol, perorangan, dan kelompok. Model pembelajarannya menggunakan pembelajaran aktif dengan berbagai strategi dan pendekatan yang berpusat pada siswa. Pembelajaran dikemas dalam program Lesson Study, yaitu tahap Plan, Do, dan See. Dalam tahapan ini juga menanamkan kesaadaran metakognitif melalui tahapan memahami, mengendaikan, dan memanipulasi proses kognisi.
\end{abstract}

Kata kunci: lingkungan sekolah, model pembelajaran, Lesson Study

\section{Pendahuluan}

Lingkungan diartikan sebagai kesatuan ruang suatu benda, daya, keadaan dan mahluk hidup termasuk manusia dan perilakunya yang mempengaruhi kelangsungan peri kehidupan dan kesejahteraan manusia serta mahluk hidup lainnya (Munib, 2005:76). Sekolah merupakan wahana kegiatan dan proses pendidikan berlangsung. Di sekolah diadakan kegiatan pendidikan, pembelajaran dan latihan (Tu'u, 2004:18). Sekolah merupakan lembaga pendidikan formal yang sistematis melaksanakan program bimbingan, pengajaran, dan latihan dalam rangka membantu siswa agar mampu megembangkan potensinya baik yang menyangkut aspek moral, spiritual, intelektual, emosional maupun sosial (Syamsu Yusuf, 200I:54).

Pada dasarnya semua jenis lingkungan yang ada di sekitar anak dapat dimanfaatkan untuk mengoptimalkan kegiatan pendidikan untuk anak usia dini sepanjang relevan dengan komptensi dasar dan hasil belajar yang bisa berupa lingkungan alam atau lingkungan fisik, lingkungan sosial dan lingkungan budaya atau buatan. Lingkungan alam atau lingkungan fisik adalah segala sesuatu yang sifatnya alamiah, seperti sumber daya alam (air, hutan, tanah, batu-batuan), tumbuh-tumbuhan dan hewan (flora dan fauna), sungai, iklim, suhu, dan sebagainya. Lingkungan alam sifatnya relatif menetap, oleh karena itu jenis lingkungan ini akan lebih mudah dikenal dan dipelajari oleh anak. Sesuai dengan kemampuannya, anak dapat mengamati perubahan- perubahan yang terjadi dan dialami dalam kehidupan sehari-hari, termasuk juga proses terjadinya. Dengan mempelajari lingkungan alam ini diharapkan anak akan lebih memahami gejala-gejala alam yang terjadi dalam kehidupannya sehari-hari, lebih dari itu diharapkan juga dapat menumbuhkan kesadaran sejak awal untuk mencintai alam, dan mungkin juga anak bisa turut berpartisipasi untuk menjaga dan memelihara lingkungan alam.

Sedangkan lingkungan pendidikan adalah berbagai faktor yang berpengaruh terhadap pendidikan atau berbagai lingkungan tempat berlangsungan proses pendidikan. Jadi lingkungan sekolah adalah kesatuan ruang dalam lembaga pendidikan formal yang memberikan pengaruh pembentukan sikap dan pengembangan potensi siswa. Namun bagaimanakah cara memanfaatkaan lingkungan sebagai sumber belajar? Tentu perlu mempertimbangkan berbagai factor dalam pembelajaran tidak hanya aspek pengajarannya, karena kalau pengaajaran hanya terbatas pada interaksi guru dan siswa. Sedang pembelajaran melibatkan semua komponen pembelajaran yaitu: guru, siswa, media, materi, evaluasi, waktu, kelas/ruang, metode pembelajaran. Media harus menjadi komponen efektif agar dapat mendukung pembelajaran efektif. Melalui media yang efektif, pembelajaran efektif, maka siswa akan belajar dengan nyaman sehingga prestasi dan hasil belajar menjadi lebih baik.

Pembelajaran melalui Lesson Study dapat meningkatkan motivasi dan pemahaman pembelajaran 
bagi guru, siswa, dan pengelola pembelajaran.Lesson Study membangkitkan minat belajar, oleh karena itu Lesson study juga meningkatkan kesadaran metakognisi baik guru maupun siswa sehingga kualitas pembelajaran menjadi lebih baik. Dalam pembelajaran ini membutuhkan media yang baik, seperti media riel yang dapat digunakan langsung oleh siswa. Lingkungan sekolah akan melengkapi pembelajaran karena siswa dapat mengamati secara langsung sehingga lebih mudah menjadikan pembelajaran menjadi bermakna.

\section{Metode Penelitian}

Metode penelitian pada dasarnya merupakan langkah-langkah atau prosedur yang akan dilakukan dalam pengumpulan, pengolahan dan analisis data untuk mendeskripsi pemecahan masalah penelitian dan menguji hipotesis.

\section{Hasil dan Pembahasan}

Macam sumber belajar yaitu sumber belajar yang memangdikembangkan dan disiapkan yang disebutdengan resources by design sumber belajar yang tidak direncanakansecara khusus untuk pengajaran, tetapidapat digunakan untuk belajar yang disebutdengan resources by utilization Adapun fungsi sumber belajar adalah sebagai sarana mengembangkan keterampilan, memproseskan perolehan, mengeratkan hubungan antara siswa, dengan lingkungan, mengembangkan pengalaman dan pengetahuan siswa, membuat proses belajar-mengajar lebih bermakna (Munadi, 2008).

Keuntungan memanfaatkan lingkungaan sebagai sumber belajar Menghemat biaya, karena memanfaatkan benda-benda yang telah ada di lingkungan, yaitu praktis dan mudah dilakukan, tidak memerlukan peralatan khusus, Memberikan pengalaman yang riil kepada siswa, pelajaran menjadi lebih konkrit, tidak verbalistik, karena benda-benda tersebut berasal dari lingkungan siswa, maka benda-benda tersebut akan sesuai dengan karakteristik dan kebutuhan siswa. Hal ini juga sesuai dengan konsep pembelajaran kontekstual (contextual learning). Pelajaran lebih aplikatif, maksudnya materi belajar yang diperoleh siswa melalui media lingkungan kemungkinan besar akan dapat diaplikasikan langsung, karena siswa akan sering menemui benda. Media lingkungan memberikan pengalaman langsung kepada siswa, dan lebih komunikatif.

Lingkungan secara alami mendorong anak untuk berinteraksi dengan komponennya, seperti dengan tumbuhan, hewa, atau manusia, dan benda mati di sekitar lingkungan.Bila guru memanfaatkan lingkungan sebagai sumber belajar, ini berarti guru telah menggunakan sumber belajar riil (sesungguhnya), bukan berupa tiruan atau model.Sumber belajar yang riilmembuat kualitas lebih baik bila dibandingkan menggunakan model atau tiruan. Siswa akan lebih tertarik dengan sesuatu yang bersifat nyata dan asli dibanding tiruan atau model. Lingkungan sebagai sumber belajar adalah objek yang menarik untuk dipelajari. Dengan menariknya sumber belajar, maka siswa tentu akan lebih bersemangat dan termotivasi. Sebagai sumber belajar riil dan menarik, lingkungan akan memberikan pembelajaran yang bermakna bagi siswa. Pembelajaran bermakna amat penting bagi siswa karena tujuan pembelajaran atau kompetensi yang diharapkan dapat dicapai dengan baik.
Belajar dengan menggunakan lingkungan sebagai sumber pembelajaran akan membuat siswa aktif, karena siswa lebih mudah berinteraksi dengan lingkungan. Adanya interaksi dalam pembelajaran akan memberikan kontribusi positif pada proses pembelajaran. Siswa yang pasif selama pembelajaran biasanya akan lebih terlibat dalam pembelajaran saat terjun ke lingkungan. Pemanfaatan lingkungan sebagai sumber belajar bagi siswa tentu saja akan menambah ragam dan memperkaya sumber belajar lain di kelas. Pembelajaran tidak lagi monoton, banyak variasi yang dapat dilakukan guru bila menggunakan sumber belajar berupa lingkungan, dan membantu siswa mengatasi kebosanan belajar di kelas. Siswa dapat memaknai lingkungan yang dipelajari, maka akan muncul dampak pengiring yang amat penting, yaitu rasa cinta terhadap lingkungan sekitar. Contoh bila siswa mempelajaripengelolaan sampah di sekolah, maka akan dapat menumbuhkan rasa cinta terhadap kebersihan di lingkungan sekolah atau di lingkungan tempat tinggal.

Lingkungan sekolah terdiri dari komponen biotik dan abiotik yang dapat digunakan sebagai sumber belajar.Sumber belajar adalah segala sesuatu yang secara sengaja atau tidak dimanfaatkan siswa dalam belajar. Pemanfaatan lingkungan sekolah sebagai sumber belajar melalui kegiatan: penanaman dan penghijauan, mengaplikasikan teknik reproduksi buatan, pembuatan bibit pohon-pohon bereproduksi, membuat pupuk kompos dari sampah yang terdapat di sekolah, pemberian nama tumbuhan, klasifikasi tumbuhan, tata kelola lingkungan, budidaya tanaman, ciri tanaman/hewan, komponen ekosistem.

\section{Sumber Belajar Lingkungan Sekolah dan Metakognitif dalam Lesson Study \\ Lesson Study bukan metode mengajar dan juga bukan} modelpembelajaran." Lesson study adalah proses kegiatan pengkajian pembelajaran secara kolaboratif dan berkelanjutan berlandaskan prinsip-prinsip kolegialitas danmutual learning untuk membangun learning community" (Syamsuri dan Ibrahim, 20II). Lesson studymerupakan proses pengkajian pembelajaran yang dilaksanakan oleh kelompok guru secara sadar terhadap pentingnya upaya peningkatan kompetensi dalam proses belajar mengajar. Harapan ideal yang ingin dicapai dalam kegiatan lesson studyini adalah membangun masyarakat belajar, sesuai dengan prinsip belajar sepanjang hayat (life long learning).

Lesson study telah berkembang sejak abad 18 di negara Jepang. Dalam Bahasa Jepang, lesson study dikenal dengan "jugyokenkyu", yang merupakan gabungan dari dua kata yaitu "jugyo" yang berarti lesson atau pembelajaran, dan "kenkyu" yang berarti studyatau kajian. Dengan demikianlesson studymerupakan proses pengkajian terhadap pembelajaran. Di Indonesia, konsep lesson study berkembang melalui program Indonesia Mathematics and Science Teacher Education Project(IMSTEP) yang diimplementasikan sejak sejak Oktober tahun 1998 di tiga IKIP, yaitu (I) IKIP Bandung (sekarang bernama Universitas Pendidikan Indonesia, UPI), (2) IKIP Yogyakarta (sekarang bernama Universitas Negeri Yogyakarta, UNY), dan (3) IKIP Malang (sekarang menjadi Universitas Negeri Malang) yang telah bekerja sama dengan JICA (Japan International Cooperation Agency). Perkembangan selanjutnya,lesson study tidak hanya dilaksanakan pada mata pelajaran MIPA, tetapi juga mata pelajaran lainnya. Demikian juga di Prodi Pendidikan Biologi Fakultas Keguruan dan Ilmu Pendidikan Universitas Muhammadiyah Malang telah sukses menyelenggarakan 
Program Lesson Study (LS) selama satu tahun (semester genap 20I0-20II dan semester ganjil 20II-20I2). Lesson Study merupakan salah satu bentuk penerapan konsep Learning Comunity (komunitas belajar), yaitu sekelompok orang yang saling belajar dari yang lain untuk meningkatkan pengetahuannya. LS telah dilaksanakan mulai tahun 2010 sampai dengan sekarang

Direktorat Jenderal Peningkatan Mutu Pendidik dan Tenaga Kependidikan (PMPTK) melihat bahwa KKG dan MGMP menjadi wadah yang tepat untuk meningkatkan kompetensi pendidik secara berkelanjutan. Oleh karena itu, lesson studyakan sangat tepat apabila dapat diterapkan menjadi salah satu kegiatan di KKG dan MGMP. Lesson study merupakan upaya terencana dan berkelanjutan untuk melakukan kajian terhadap proses belajar mengajar, untuk kepentingan perbaikan atau peningkatan efektivitas pembelajaran bagi guru yang secara kolegial bermanfaat untuk kepentingan perbaikan dan peningkatan efektivitas pembelajaran bagi guru-guru yang lain di sekolah atau di lingkungannya.

Secara singkat, lesson study dapat dijelaskan dengan langkah-langkah sebagai berikut: Pertama, adakanlah pertemuan kelompok guru menyepakati beberapa hal, misalnya: (I) proses pembelajaran dalam pokok bahasan apa, mata pelajaran apa, dan kelas berapa, yang akan dikaji melalui lesson study; (2) siapa yang akan bertindak sebagai guru penyaji yang akan melaksanakan proses pembelajaran, (3) siapa saja guru yang bertindak menjadi pengamat dalam kegiatan lesson studytersebut. Kedua, mencoba membuat lesson plan atau Rencana Pelaksanaan Pembelajaran (RPP) bersama.Kedua tahapan ini disebut sebagai tahapan PLAN. Ketiga, jika rencana sudah matang, maka tahapan berikutnya adalah proses pelaksanaan pembelajaran. Guru penyaji melaksanakan proses pembelajaran di kelas, para pengamat mengamati proses pembelajaran, mulai dari membuka pelajaran, sampai dengan pelaksanaan pembelajaran dengan menggunakan metode dan media atau alat bantu pembelajaran, dan akhirnya sampai dengan menutup pembelajaran. Para pengamat melakukan pengamatan dan mencatatnya secara cermat. Dalam lesson study, tahapan ini dikenal sebagai tahapan DO. Keempat, para guru mengadakan pertemuan untuk mendiskusikan hasil pengamatan dari guru-guru yang lain. Dalam diskusi ini, disampaikan tentang apahasil evaluasi terhadap proses pembelajaran khususnya perubahan tingkah laku siswa selama pebelajaran. Bagaimana respon siswa terhadap komponen pembelajaran yang digunakan guru.Bagaimanakah guru memberikan respon terhadap tingkah laku siswa, serta adakah pemasalahan selama pembelajaran.Apakah upaya yan dilakaukan agar pembelajaran menjadi efektif. Hasil kesimpulan ini sebaiknya disusun secara tertulis, dan kemudian disebarluaskan kepada guru-guru yang lain, terutama yang menjadi penyaji dan pengamat dalam kegiatan lesson study tersebut. Tahapan ketiga lesson study ini dikenal dengan tahapan SEE. Oleh karena itu dalam pertemuan tersebut dapat disepakati misalnya memperbaiki RPP, atau dipilih atau disepakati guru penyaji yang lain untuk menyajikan pembelajaran, atau juga disepakati akan dilaksanakan di kelas atau sekolah yang lain. Jika keputusannya demikian, maka lessson study dapat dilaksanakan dalam tahapan replikasi berikutnya dengan ketiga tahapan berikutnya, dengan tahapan yang mendahului, yakni tahapan REVISI. Dengan demikian, jika tahapan lesson study dilakukan dalam tiga tahapan, yakni (I) PLAN, (2) DO, dan (3) SEE, maka lesson study juga dapat dilaksanakan dalam enam tahapan, yakni: (I) PLAN, (2) DO, (3) SEE, (4) REVISED PLAN, (5) DO, (6) SEE.

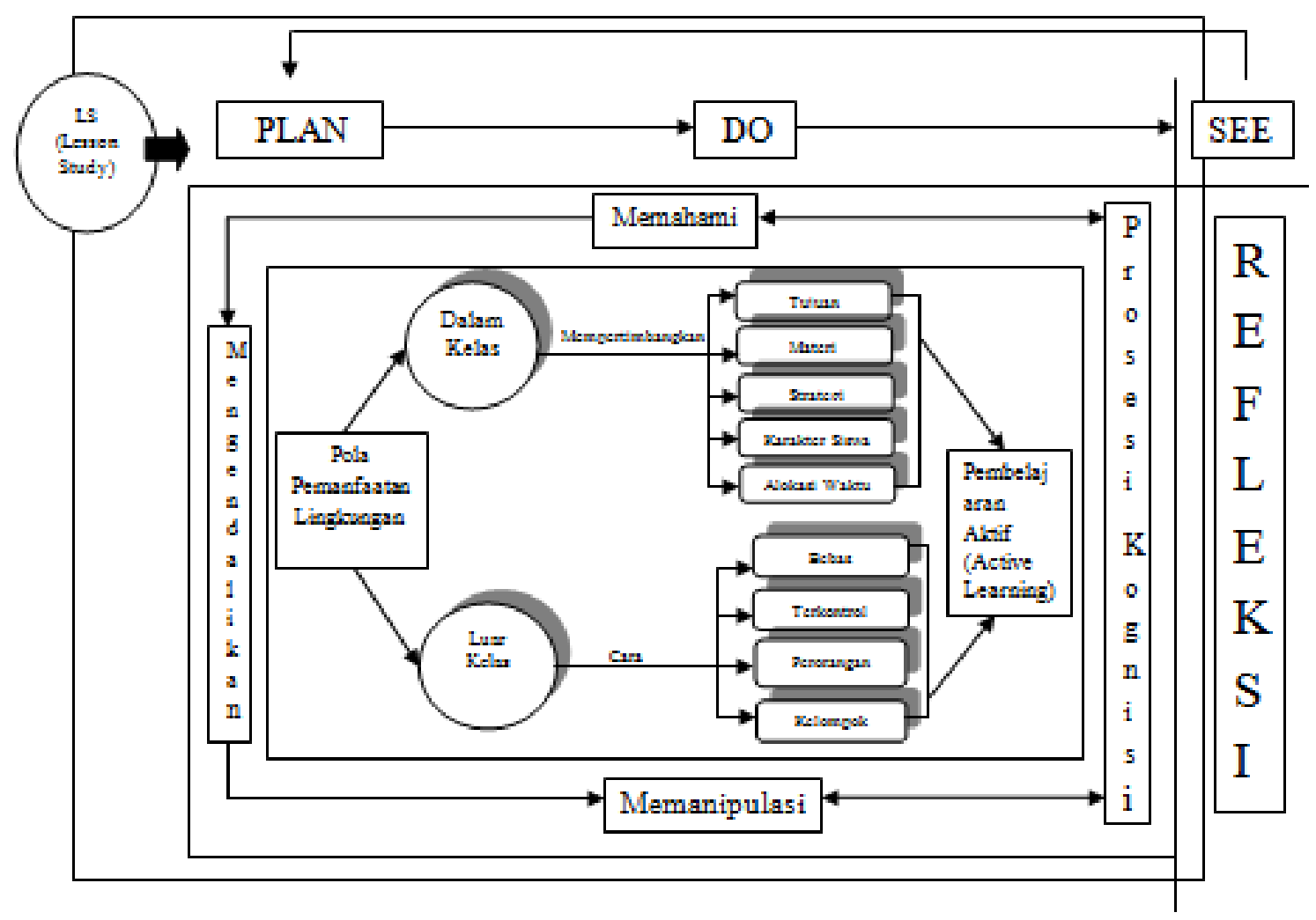

Gambar I. Keterkaitan Sumber Belajar, Metakognitif, dan Lesson Study 
Penerapan Lesson Study tidak selalu dilaksanakan di dalam kelas, guru bisa lebih kreatif dengan membawa siswa belajar di luar kelas.Pembelajaran di dalam kelas dapat membawa lingkungan sekolah ke dalam kelas, dengan demikian sumber belajar bukan lingkungan secara riel tetapi lingkungan dapat dikemas dalam bentuk media yang lain seperti, media grafis, video, radio, bahan ajar cetak. Pembelajaran memanfaatkan lingkungan sebagai sumber belajar dapat diterapkan dengan berbagai metode dan model pembelajaran, seperti Descovery, Inquiry, contexstual teaching and learning, atau problem based learning yang dapat dikemas dalam pembelajaran aktif, atau ada yang mengenal dengan sebutan PAKEM, yaitu pembelajaran aktif, kreatif, efektif, dan menyenangkan.

Model pembelajaran ini dapat dikemas dalam Lesson Study, yaitu merupakan salah satu bentuk penerapan konsep Learning Comunity (komunitas belajar), dimana sekelompok orang yang saling belajar dari yang lain untuk meningkatkan pengetahuannya. Lesson study dipilih dan dimplementasikan karena beberapa alasan. Pertama, lesson study merupakan suatu cara efektif yang dapat meningkatkan kualitas pembelajaran yang dilakukan guru dan aktivitas belajar siswa. Hal ini karena (I) pengembangan lesson study dilakukan dan didasarkan pada hasil "sharing" pengetahuan profesional yang berlandaskan pada praktik dan hasil pengajaran yang dilaksanakan para guru, (2) penekanan mendasar pada pelaksanaan suatu lesson study adalah agar para siswa memiliki kualitas belajar, (3) kompetensi yang diharapkan dimiliki siswa, dijadikan fokus dan titik perhatian utama dalam pembelajaran di kelas, (4) berdasarkan pengalaman real di kelas, lesson study mampu menjadi landasan bagi pengembangan pembelajaran, dan (5) lesson study akan menempatkan peran para guru sebagai peneliti pembelajaran (Lewis, 2002). Kedua, lesson study yang didisain dengan baik akan menjadikan guru yang profesional dan inovatif. Dengan melaksanakan lesson study para guru dapat (I) menentukan kompetensi yang perlu dimiliki siswa, merencanakan dan melaksanakan pembelajaran (lesson) yang efektif; (2) mengkaji dan meningkatkan pelajaran yang bermanfaat bagi siswa; (3) memperdalam pengetahuan tentang mata pelajaran yang disajikan para guru; (4) menentukan standar kompetensi yang akan dicapai para siswa; (5) merencanakan pelajaran secara kolaboratif; (6) mengkaji secara teliti belajar dan perilaku siswa; (7) mengembangkan pengetahuan pembelajaran yang dapat diandalkan; dan (8) melakukan refleksi terhadap pengajaran yang dilaksanakannya berdasarkan pandangan siswa dan koleganya (Lewis, 2002).

Wang-Iverson dan Yoshida (2005) mengatakan bahwa Lesson Study memiliki beberapa manfaat, yaitu I).Mengurangi keterasingan guru (dari komunitasnya), 2).Membantu guru untuk mengobservasi dan mengkritisi pembelajarannya, 3). Memperdalam pemahaman guru tentang materi pelajaran, cakupan dan urutan materi dalam kurikulum. 4). Membantu guru memfokuskan bantuannya pada seluruh aktivitas belajar siswa.
5). Menciptakan terjadinya pertukaran pengetahuan tentang pemahaman berpikir dan belajar siswa. 6). Meningkatkan kolaborasi pada sesama guru. Program Lesson Study telah membawa keberhasilan secara nyata dan bermakna. Bermakna dalam arti program Lesson Study diharapkan melekat daan berkembang, secara disadari atau tanpa disadari harus menjadi bagian yang dapat mengembangkan profesionalitas pendidik semua pihak terutama yang telah melaksanakan Lesson Study. Lesson Study merupakan Model pembinaan profesi pendidik melalui pengkajian pembelajaran secara kolaboratif danberkelanjutan berlandaskan prinsipprinsip kolegalitas dan mutual learning untuk membangun komunitas belajar sebagai mutu pendidikan yang tak pernah berakhir (continous improvement). Meningkatnya mutu pendidikan tentu sebagai perwujudan meningkatnya pembelajaran oleh guru bersama siswa dan komponen pembelajaran lainnya yang dievaluasi dari indilator mutu termasuk didalamnya hasil dan proses pembelajaran. Peningkatan hasil dan proses belajar sebagai indikasi keberhasilan upaya guru dalam kreativitas dan inovasi pembelajaran yang diikuti dengan meningkatnya minat dan motivasi belajar siswa. Kualitas pembelajaran menjadi meningkat sehingga membawa keberhasilan pada mutu pembelajaran dan pendidikan secara menyeluruh. Dalam keberhasilan ini tidak terlepas dari adanya perubahan guru dan siswa dalam proses berpikir yang mengalami pergeseran dan perubahan. Guru dan siswa telah mengalami peristiwa metakognisi. Istilah Metakognitif biasa disebut dengan metakognisi (metacognition) yang ditemukan oleh seorang ilmuwan pendidikan yang bernama Flavell (1979). Metakognisi tidak hanya sebatas kognitif atau berpikir saja tapi satu tingkat lebih tinggi dari berpikir atau biasa disebut dengan thinking about thinking yang artinya berpikir tentang proses berpikir itu sendiri. Dengan demikian metakognitif adalah sebuah kemampuan manusia untuk mengendalikan atau pemantauan pikiran, kalau diterapkan dalam dunia pendidikan bahasa aplikasinya metakognitif merupakan kemampuan peserta didik atau siswa dalam memonitor (mengawasi), merencanakan serta mengevaluasi sebuah proses pembelajaran. Bila guru atau siswa menerapkan strategi metakognitif diharapkan mampu bersikap mandiri dalam hal materi atau ilmu yang dipelajari, bersikap jujur terhadap kemampuan masing-masing diri baik kekurangan dan kelebihan yang dimiliki, dan berani mencoba perkara baru guna menggali pengetahuan dan meningkatkan kemampuannya. Dalam kegiatan berpikir, hal ini disebut dengan istilah metakognitif. Program Lesson Study di dalamnya merupakan proses pembelajaran yang dilaksanakan berhubungan dengan ranah kognitif, afektif, dan psikomotor dan disertai pembelajaran metakognitif. Melalui program Lesson Study dapat meningkatkan kesadaran peserta terhadap apa yang telah dipelajari. Pengalaman peserta dapat dikatakan berkualitas apabila peserta Lesson Study secara sadar mampu mengontrol proses kognitifnya secara berkesinambungan dan 
berdampak pada peningkatan kemampuan metakognitif. Oleh karena itu perlu di ketahui dan dianalisis bagaimanakah kesadaran metakognitif para peserta Lesson Study.

Implementasi Lesson Study membawa dampak besar pada iklim pembelajaran baik kepada model pembelajaran maupun observer, bahkan panitia penyelenggara atau pengelola. Meningkatnya kolegialitas antar dosen/guru pengampu mata kuliah juga siswa dan mahasiswa merupakan bukti kesadaran metakognitif sudah muncul dan terjadi dalam diri seseorang. Kesadaran Metakognitif, atau metakognisi, pertama kali didefinisikan oleh Flavell (1979), sebagai kemampuan seseorang memahami, mengendalikan, dan memanipulasi proses kognitif. Bila seseorang telah dapat mengelola proses kognitifnya dengan, maka seseoraang itu akan lebih mudah dalam menentukan strattegi yang akan digunakan dalam melakukan tahapan belajar berikutnya

Menurut Arends (1997) metakognitif adalah pengetahuan seseorang tentang pembelajaran diri sendiri atau berfikir tentang kemampuannya untuk menggunakan strategi-strategi belajar tertentu dengan benar. Dengan demikian metakognitif adalah kemampuan untuk mengontrol ranah atau aspek kognitif, mengendalikan enam tingkatan aspek kognitif yang didefinisikan oleh Benjamin Bloom dalam taksonomi Bloom yang terdiri dari tahap ingatan, pemahaman, terapan, analisis, sintetis, dan evaluasi. Para partisipan dan model dalam program Lesson Study telah mengenal dirinya, telah muncu kesadaraan metakognisinya sehingga tahapan berikutnya adalah menentuan strategi metakognitif agar pemikiran, aktifitas dan target kegiatan berikutnya dapat tercapai. Fogarty (1994) menunjukkan bahwa metakognisi adalah proses yang mencakup tiga tahap yang berbeda, dan untukmenjadi pemikir yang berhasil, siswa harus melakukan hal berikut:I). Mengembangkan rencana sebelum melakukan pembelajaran, , seperti membaca untuk pemahaman atau memecahkan masalah, 2). Memantau pemahaman dengan menggunakan strategi ketika memecah masalah, 3) mengevaluasi pemikiran siswa setelah menyelesaikan tugas.

Lesson Study, dengan kelebihannya mampu meningkatkan motivasi dan inovasi guru dalam pembelajaran. Peningkatan ini tidak terlepas dari kenaikan kemampuan berpikir juga metakognitif baik bagi guru maupun siswa. Pelaksanaan pembelajarannya menjadi lebih baik bila didukung media dan sumber belajar yang sesuai. Strategi Pemanfaatan Media dalam pembelajaran dan fungsi pemanfaatan adalah penting, karena membicarakan kaitan antara siswa dengan bahan atau sistem pembelajaran. Pemanfaatan media berarti penggunaan yang sistematis dari sumber untuk belajar (AECT, 1994). Proses pemanfaatan media merupakan proses pengambilan keputusan berdasarkan pada spesifikasi desain pembelajaran.Seseorang yang belajar memerlukan bantuan keterampilan visual atau verbal agar dapat menarik keuntungan dari praktek atau sumber belajar. Dalam prakteknya, pemanfaatan media dan sumber belajar dilakukan dengan menggunakan beberapa pola.Sadiman (1999) menggunakan 2 (dua) pola pemanfaatan, yaitu pola pemanfaatan media dalam situasi kelas dan pola pemanfaatan media di luar situasi kelas. Penjelasan kedua pola tersebut dijelaskan lebih lanjut sebagai berikut: I). Pola Pemanfaatan Media dalam situasi kelas, yaitu pemanfaatan media dalam situasi kelas adalah penggunaannya dipadukan dengan proses belajar mengajar dalam situasi kelas, dalam merencanakan pemanfaatannya harus mempertimbangkan hal-hal seperti: tujuan yang akan dicapai, materi pembelajaran yang mendukung tercapainya tujuan, dan strategi pembelajaran yang sesuai untuk mencapai tujuan. Jadi penggunaan atau pemanfaatan media dalam situasi kelas adalah benar-benar harus mempertimbangkan ketiga hal tersebut. Selain itu yang terpenting adalah media yang disajikan di ruang kelas di mana guru dan siswa hadir bersama-sama dapat berinteraksi secara langsung (face to face). Disamping mempertimbangkan ketiga hal di atas juga tentunya harus memungkinkan dilihat dari sisi biaya, berat dan ukuran, kemampuan siswa untuk menggunakannya dan tidak membahayakan bagi penggunanya atau dengan kata lain harus praktis, ekonomis, dan mudah untuk digunakannya. 2). Pola Pemanfaatan Media di luar situasi kelas. Dalam pemanfaatan media di luar situasi kelas ini ada beberapa cara, yaitu pemanfaatan secara bebas, secara terkontrol, perorangan dan cara kelompok. Pemanfatan media secara bebas adalah media yang digunakan tanpa diawasi dan dikontrol, pemakai menggunakan menurut kebutuhan masing-masing. Pola pemanfaatan media di luar situasi kelas yang terkontrol adalah media yang digunakan dalam rangkaian kegiatan diatur secara sistematik untuk mencapai tujuan tertentu. Sedangkan yang terakhir yaitu cara pemanfaatan media untuk perseorangan atau sendirian saja, dan juga untuk kelompok atau masal.

Media dan sumber belajar lingkungan yang dekat dengan siswa adalah lingkungan sekolah. Adapun pemanfaatana lingkungan sebagaai sumber belajar sekaligus sebagai upaya menjaga kelestarian lingkungan sekolah, yaitu digunakan sebagai berikut:

I. Menyusun dan memasyarakatkan perogram sekolah hijau.

2. Mendaftar atau menginvestasikan dan melaksanakan perogram sekolah hijau

3. Membangun kegiatan apotek hidup di sekolah.

4. Mengurangi atau menghemat penggunaan lampu pendingin ruang kelas, konsumsi air dan energi lainnya.

5. Membangun mekanisme pembuangan sampah di sekolah.

6. Membiasakan untuk kegiatan hemat atau bahkan mendaur ulang semua kertas, plastik dan sejenisnya

7. Menyediakan tempat sampah berdasarkan jenis sampahnya. 
8. mengkondisikan kegiatan ekstra kulikuler berbasis lingkungan, seperti kelompok hijau, pecinta alam dan sejenisnya.

9. Melakukan diskusi atau studi kasus tentang pemeliharaan lingkungan sekolah dan sejenisnya

I0. Mengadakan karya wisata atau studi banding dalam rangka pemeliharaan dan peningkatan kebersihan dan kelestarian laingkungan sekolah

II. Melaksanakan tata tertib kebersihan dan kelestarian lingkungan sekolah.

12. Mengembangkan kecintaan dan kepedulian siswa terhadap lingkungan sekolah melalui berbagai loba peduli lingkungan, seperti lomba kebersihan antar kelas, menulis, menggambar, atau aneka kreativitas lain yang bersifat ramah lingkungan.

I3. Mengadakan pengawasan dan penegakan kedisiplinan.

I4. Mengadakan gerakan cinta kebersihan dan kesehatan lingkungan sekolah

I5. memanfaatkan hari-hari besar nasional untuk gerak peduli lingkungan

16. Secara keseluruhan, kebersihan dan keasrian sekolah adalah tanggung jawab bersama dari setiap warga sekolah.

Selain guru dan siswa, pemeliharaan dan perwujudan lingkungan sekolah yang bersih, sehat, dan asri tidak lepas dari peran orang tua, lembaga swadaya masyarakat mau pun pemerintah. Kondisi demikian akan melahirkan siswa yang cerdas, bermutu, berwawasan lingkungan serta mampu menerapkan sikap cinta dan peduli lingkungannya di lingkungan sekolah maupun masyarakan.

\section{Simpulan}

Pemanfaatan lingkungan sebagai sumber belajar menggunakan dua pola, yaitu pola di dalam kelas dan di luar kelas. Kedua pola ini dapat digunakan dalam pembelajaran melalui program Lesson study, yang diharapkan dapat menjadi wahana proses pembelajaran bagi guru untuk belajar dan berlatih dalam upaya peningkatan kompetensi guru. Kegiatan Lesson Study telah dilakukan oleh para guru, dosen, dan pemerhati penddidikan, dapat meningkatkan kesadaran metakognitif peserta sehingga muncul keterampilan strategi metakognitifnya untuk mengembangkan diri bahkan mengembangkan lembaga.

\section{Daftar Pustaka}

Brown, James Wilson, AV 1983 Instruction: Tacnology, media, and Methods, Book Company: McGraw-Hill,

Flavel.1979. Metacognition and Cognitive Monitoring: a New Area of Cognitive Developmental Inquiry. American Psychologist, 34, 906-9II.

Munadi, Yudhi. 2008. Media Pembelajaran. Jakarta: Gaung Persada Press
Sadiman, Arief, dkk. I984. Media Pendidikan. Jakarta: PT Raja Grafindo Persada

Schramm, Wilbur, 1977. Big Media Little Media: Tolls ang verly Hills, California,

Slameto.2003.Belajar dan Faktor-faktor yang Mempengaruhinya.Jakarta:Rineka Cipta.

Sudjana \& A. Rifai. 2000. Sumber Belajar dan Alat Pelajaran. Jakarta: Bumi Aksara.

Syamsuri, Istamar \& Ibrohim. 20I I. Lesson Study (Studi Pembelajaran). Malang: IKIP Malang

Tu'u,Tulus.2004. Peran Disiplin pada Perilaku dan Prestasi Siswa. Jakarta: Rineka Cipta.

Warsito, B. 2008. Teori Belajar Robert M. Gagne dan Implikasinya pada Pentingnya Pusat Sumber Belajar. Jurnal Teknodik. Vol XII (OI). 